\title{
Foreword: Innovation and dedication underpin management of sudden oak death (Phytophthora ramorum) in California and Oregon forests
}

\author{
Susan J. Frankel, USDA Forest Service, Pacific Southwest Research Station, 800 Buchanan Street, \\ Albany, CA, 94710; sfrankel@fs.fed.us
}

This special issue of Forest Phytophthoras serves as part of the proceedings from the Sixth Sudden Oak Death Science Symposium held June 21 - 23, 2016 at Fort Mason Center in San Francisco, CA, USA. The symposium marked almost 16 years to the day that David Rizzo (UC Davis) and Matteo Garbelotto (UC Berkeley) identified the cause of sudden oak death to be a previously unknown Phytophthora species, later named Phytophthora ramorum. Many of the approximately 200 participants at the conference have dedicated the past 15 years, a large portion of their life's work, to protect U.S. forests from this new invasive pathogen.

The papers collected in this issue focus on direct actions taken in the forest to arrest $P$. ramorum infestations in California and Oregon. Despite mixed success in terms of pathogen eradication or suppression, these efforts comprise the most comprehensive fight against a forest pathogen in the U.S. since the campaigns, from about 1915 - 1970, to remove Ribes to control white pine blister rust (Cronartium ribicola) (Maloy 1997, Geils et al. 2010).

Taken together, these papers show how difficult it is to cure even a single tree, let alone prevent spread, manage, and control a new, invasive forest pathogen. Despite technological leaps in diagnostics, our management tools and strategies remain somewhat primitive, focusing primarily on hot spot eradication which removes individuals of the host species that we are trying to save. For successful pathogen eradication, the pest must be detected very early, before it spreads further (Hansen et al. 2008), which remains challenging not only for $P$. ramorum but for other highly damaging invasive species such as Asian longhorned beetle (Anoplophora glabripennis) and emerald ash borer (Agrilus planipennis) (GAO 2006).

So if the post-establishment management approaches described in this issue, primarily eradication, silvicultural manipulations, or pesticide treatment, haven't been totally successful, how effective are indirect approaches or preventive measures, such as quarantine regulations? Federal and state regulations (ODA 2001, USDA 2002, CDFA 2003) were enacted to prevent human-assisted long-distance pathogen spread; they primarily target nursery plant shipments of Rhododendron, Camellia, Viburnum, Pieris, and Kalmia, but cover all 100+ plant species known to be P. ramorum hosts (USDA 2013). Unfortunately, quarantines have failed to achieve desired results, as shown in Goheen et al. (this volume). Regulations did not prevent the introduction, in about 2014, of a more aggressive lineage (EU1) into an Oregon forest, nor did they prevent the shipment of over 1 million potentially infested plants from a few nurseries in California and Oregon in 2004 (Stokstad 2004). Those 2004 shipments demonstrate the threat large commercial nurseries pose for pathogen dispersal: a California nursery that supplied over 5,000 nurseries nationwide was found to be infested with $P$. ramorum but only after plants had been shipped to more than 20 states (Drew 2010, Kliejunas 2010). 
Looking back at the over 20 years since the recognition of unprecedented mortality of tanoaks (Notholithocarpus densiflorus) and coast live oaks (Quercus agrifolia) on the flanks of Mt. Tamalpais (Marin County, CA), while we have not managed or prevented all P. ramorum spread, many technological advances have improved our understanding of $P$. ramorum, and our ability to combat it. The epidemic emerged coincident with a digital and genetic-methods revolution which enhanced all aspects of forest pathogen response. For example, documentation of pathways of long distance spread has improved due to genetically-based pathogen identification (i.e. DNA finger-printing) (Goss et al. 2009, Grünwald et al. 2012, Grünwald et al. 2016). Within the USA, across Europe and between continents, data has proven that $P$. ramorum moved to new areas numerous times on nursery stock, where it then could escape to the adjacent environment or be inadvertently planted in a landscape (Grünwald et al. 2012, Kamvar et al. 2015).

Other innovations include the sequencing of $P$. ramorum's genome, just a few years after the microbe's discovery, which provided insights into pathogen biology (Tyler et al. 2006); development of an online, publically accessible geographic information system (GIS) map, oak mapper (www.oakmapper.org, Kelly, 2017) and a mobile application, SOD map (Garbelotto et al. 2014); and improved statistical models that account for epidemiology, vegetation composition, spatial and topographic factors (Václavik et al. 2010, Meentemeyer et al. 2011, Meentemeyer et al. 2012, Cunniffe et al. 2016). Molecular hostpathogen interactions were elucidated in the first reference transcriptome for tanoak, allowing the preliminary identification of disease-related genes (Hayden et al. 2014). The value of large ecological datasets has been demonstrated dramatically, showing fire and $P$. ramorum interactions in Big Sur (Monterey Co.), when wildfires burned through infested areas containing previously established plots (Metz et al. 2011, Metz et al. this volume).

Also creative were new sources of financial support: sudden oak death marked the first time that emergency funds from the USDA Farm Service Agency, Commodity Credit Corporation, supported research to respond to a forest health emergency (Shea 2006). In 2001-2002, those funds, along with a supplemental appropriation from Congress, enabled the establishment of the USDA Forest Service, Pacific Southwest Research, Sudden Oak Death Research program (Shea 2006, COMTF 2017). Foundation awards (e.g. The Gordon and Betty Moore Foundation) and partnerships played a larger role in supporting and coordinating research than in previous pathogen epidemics.

\section{Conclusions}

Progressive hops in understanding keep us headed forward, yet our society's ability to control $P$. ramorum or other invasive forest pathogens remains limited. To control a new, invasive wildland pathogen requires a complex, costly and logistically challenging campaign. Coordinated efforts are required of local, state, regional and federal legislators, administrators and stakeholders to support financial and human resource investments for regulation design and enforcement, management, research, monitoring, policy development, education and outreach. Each step requires decisions to be made within numerous organizations and collectively, across agencies and disciplines, since no single entity alone has responsibility or resources to address a forest health epidemic. Additional research to measure and record the efficacy of control operations is needed and could help inform development of a broad consensus to more clearly define action thresholds, both for initiation and termination of management actions. The management experience and incremental advances achieved during our fight against $P$. ramorum provide a stronger foundation for future invasive species incursions. 


\section{Literature cited}

California Department of Food and Agriculture. 2003. Oak mortality disease control. Plant Quarantine Manual 455.1-455.6.

California Oak Mortality Task Force. 2017. A chronology of Phytophthora ramorum, cause of sudden oak death and other foliar diseases, http://www.suddenoakdeath.org/library/comtf-program-documents/. [Accessed August 22, $2017]$.

Cunniffe, N. J., Cobb, R. C., Meentemeyer, R. K., Rizzo, D. M., and Gilligan, C. A. 2016. Modeling when, where, and how to manage a forest epidemic, motivated by sudden oak death in California. Proc. Natl. Acad. Sci. USA 113(20):5640-5645.

Drew, J., Anderson, N., and Andow, D. 2010. Conundrums of a complex vector for invasive species control: A detailed examination of the horticultural industry. Biol. Invasions 12(8):2837-2851.

Garbelotto, M., Maddison, E. R., Schmidt, D. 2014. SODmap and SODmap mobile: two tools to monitor the spread of sudden oak death. For. Phytophthoras 4(1). doi: 10.5399/osu/fp.4.1.3560.

Geils, B.W., Hummer, K.E., and Hunt. R. S. 2010. White pines, Ribes, and blister rust: a review and synthesis. For. Pathol. 40(3-4):147-185.

Goss, E. M., Carbone, I., and Grünwald, N. J. 2009. Ancient isolation and independent evolution of the three clonal lineages of the exotic sudden oak death pathogen Phytophthora ramorum. Mol. Ecol. 18(6):1161-1174.

Government Accountability Office. 2006. Invasive forest pests: lessons learned from three recent infestations may aid in managing future efforts. GAO-06-353. $125 \mathrm{p}$.

Grünwald, N. J., Garbelotto, M., Goss, E.M., Heungens, K., and Prospero, S. 2012. Emergence of the sudden oak death pathogen Phytophthora ramorum. Trends Microbiol. 20:131-138.

Grünwald, N. J., McDonald, B. A., and Milgroom, M.G. 2016. Population genomics of fungal and oomycete pathogens. Annu. Rev. Phytopathol. 54:323-46.

Hansen, E. M., Kanaskie, A., Prospero, S., McWilliams, M., Goheen, E. M., Osterbauer, N., Reeser, P., Sutton, W. 2008. Epidemiology of Phytophthora ramorum in Oregon tanoak forests. Can. J. For. Res. 38(5):1133-1143.

Hayden, K. J., Garbelotto, M., Knaus, B. J., Cronn, R. C., Rai, H., and Wright, J. W. 2014. Dual RNA-seq of the plant pathogen Phytophthora ramorum and its tanoak host. Tree Genet. \& Genomes 10(3):489-502.

Kamvar, Z. N., Larsen, M. M., Kanaskie, A. M., Hansen, E. M., and Grünwald, N. J. 2015. Spatial and temporal analysis of populations of the sudden oak death pathogen in Oregon forests. Phytopathology 105(7): $982-989$.

Kelly, M. 2017. Oak Mapper 2.0, http://oakmapper.org/. [Accessed August 22, 2017].

Kliejunas, J. T. 2010. Sudden oak death and Phytophthora ramorum: a summary of the literature. 2010 ed. Gen. Tech. Rep. PSW-GTR-234. Albany, CA: U.S. Department of Agriculture, Forest Service, Pacific Southwest Research Station. 181 p.

Maloy, O. C. 1997. White pine blister rust control in North America: a case history. Annu. Rev. Phytopathol. 35(1):87-109.

Meentemeyer, R. K., Cunniffe, N. J., Cook, A. R., Filipe, J. A., Hunter, R. D., Rizzo, D. M., and Gilligan, C A. 2011. Epidemiological modeling of invasion in heterogeneous landscapes: spread of sudden oak death in California (1990-2030). Ecosphere 2(2):1-24.

Meentemeyer, R. K., Haas, S. E., and Václavík, T. 2012. Landscape epidemiology of emerging infectious diseases in natural and human-altered ecosystems. Annu. Rev. Phytopathol. 50:379-402.

Metz, M. R., Frangioso, K. M., Meentemeyer, R K., and Rizzo, D. M. 2011. Interacting disturbances: wildfire severity affected by stage of forest disease invasion. Ecol. Appl. 21(2): 313-320. 
Oregon Department of Agriculture. 2001. Quarantine: Phytophthora ramorum. ORS 603-052-1230, Division 52, Pest and Disease Control.

Shea, P. J. 2006. USDA Forest Service, Pacific Southwest Research Station Sudden Oak Death Research Program: 2001 - 2005. Pages 7-9 in: Frankel, S.J.; Shea, P.J.; Haverty, M.I., tech. coords. Proceedings of the sudden oak death second science symposium: the state of our knowledge. Gen. Tech. Rep. PSW-GTR-196. Albany, CA: Pacific Southwest Research Station, Forest Service, U.S. Department of Agriculture.

Stokstad, E. 2004. Nurseries may have shipped sudden oak death pathogen nationwide. Science 303:1959.

Tyler, B. M., Tripathy, S., Zhang, X., Dehal, P., Jiang, R .H. Y., Aerts, A., Arredondo, F. D., Baxter, L., Bensasson, D., Beynon, J. L., Chapman, J., Damasceno, C .M .B., Dorrance, A. E., Dou, D., Dickerman, A. W., Dubchak, I. L., Garbelotto, M., Gijzen, M., Gordon, S. G., Govers, F., Grünwald, N. J., Huang, W., Ivors, K. L., Jones, R. W., Kamoun, S., Krampis, K., Lamour, K. H., Lee, M.-K., McDonald, W. H., Medina, M., Meijer, H .J. G., Nordberg, E. K., Maclean, D. J., Ospina-Giraldo, M. D., Morris, P. F., Phuntumart, V., Putnam, N. H., Rash, S., Rose, J. K .C., Sakihama, Y., Salamov, A .A., Savidor, A., Scheuring, C. F., Smith, B. M., Sobral, B. W. S., Terry, A., TortoAlalibo, T. A., Win, J., Xu, Z., Zhang, H., Grigoriev, I. V., Rokhsar, D. S. and Boore, J. L. 2006. Phytophthora genome sequences uncover evolutionary origins and mechanisms of pathogenesis. Science 313:1261-1266.

USDA Animal Plant Health Inspection Service. 2002. Phytophthora ramorum: quarantine and regulations. 7 CFR Part 301 Federal Register 67(31):6827-6837.

USDA Animal Plant Health Inspection Service. 2013. List of regulated hosts and plants proven or associated with Phytophthora ramorum.

https://www.aphis.usda.gov/plant health/plant pest info/pram/downloads/pdf files/usdaprlist.pdf. [Accessed August 22, 2017].

Václavik, T.; Kanaskie, A., Hansen, E.M., Ohmann, J.L., Meentemeyer, R.K. 2010. Predicting potential and actual distribution of sudden oak death in Oregon: prioritizing landscape contexts for early detection and eradication of disease outbreaks. For. Ecol. Manage. 260(6):1026-1035. 